\title{
Stocks Abnormal Returns and Rate of Dividend Announcements
}

\author{
Nagendra Marisetty ${ }^{1} \&$ M Suresh Babu ${ }^{2}$ \\ ${ }^{1}$ Faculty, Reva Business School, Reva University, Bangalore, Karnataka, India \\ ${ }^{2}$ Retired Professor, Sri Venkateshwara University, Tirupati, Andhra Pradesh, India \\ Corresponding author: Nagendra Marisetty, Faculty, Reva Business School, Reva University, Bangalore, \\ Karnataka, India. E-mail: nagendra.marisetty@gmail.com
}

Received: September 1, 2021

Accepted: September 18, 2021

Online Published: September 21, 2021

doi:10.5539/ijbm.v16n11p33

URL: https://doi.org/10.5539/ijbm.v16n11p33

\begin{abstract}
The present research study examined the impact of different dividend rate announcements on stocks prices in the Indian stock market. Stocks selected from S\&P BSE 500 index and study period from $2008-2017$. The sample used for this study is 1755 pure cash dividend announcements (492 large-caps, 425 mid-caps, and 838 small-caps). Dividend rates are classified into six classifications to test the stocks' abnormal returns to different dividend classifications. Event methodology market model used to calculate Average Abnormal Returns (AAR) and Cumulative Average Abnormal Returns (CAAR). The results were observed twenty-one times based on market capitalization and dividend rate wise for a final dividend announcement. The results of the study are not the same for different dividend rate classifications and different market capitalizations. The study found positive abnormal returns on event day in most of the classifications, and it is similar to Litzenberger and Ramaswamy (1982), Asquith and Mullins Jr (1983), Grinblatt, Masulis and Titman (1984), Chen, Nieh, Da Chen, and Tang (2009) and many previous research results studied in major developed stock markets and emerging stock markets. Full sample and small-cap final dividend rate 100 percent to 199 percent average abnormal returns are positively significant, and other final dividend rate classification abnormal returns are positive in most of the observations, but returns are not significant. Large-cap average abnormal returns are more sensitive to different dividend rates, and small-cap reacts positively in all classifications. So, different market capitalization final dividend actions impact on stocks in India varies in different dividend rate classifications.
\end{abstract}

Keywords: stock abnormal returns, rate of dividend percentage, event study model, Indian stock market

\section{Introduction}

In the last fifteen years, the world economy has suffered primarily due to the event of economic issues and adverse shocks, for example, beginning with the 2008-2009 world financial crisis, the 2010-2012 European Union Sovereign crisis, and the 2014-2016 Global Commodity Price realignment. As these issues got better, the global economy strengthened, providing a broader scope to reorient policies towards development along with the social, economic, and environmental aspects of sustainable progress. World economic growth estimated to reach 3 percent in the year 2017, a remarkable increase compared to 2.4 percent in the year 2016. Most of the market indicators continue to increase in a broad spectrum of countries, and around two-thirds of the around the world experienced an improved growth in 2017 than the previous year. At the world level, growth was forecasted to be at 3 percent in the years 2018 and 2019. The rapid growth in the economy comes mainly from several developed countries, in spite of East and Southeast Asia, India, the global most dynamic areas.

India, during the period 2003 to 2007, observed around 9 percent Gross Domestic Product (GDP) growth rate. However, after 2008, the global financial crisis growth rate was moderate. At the beginning of 2012, India experienced a decrease in growth rate almost as low as 5.6 percent because of economic problems like depreciating Indian rupee, high current deficit, sluggish industrial growth and many more related reasons. In the period 2013-2014, India's GDP growth rate increased to 6.4 percent from the previous year 5.5 percent and an increasing growth trend continued in the years 2014-2015 and 2015-2016 with rates of 7.5 percent and 8 percent, respectively. However, GDP growth rates decreased in the years 2016-2017 and 2017-2018 with rates of 7.1 percent and 6.6 percent respectively, but 2018-2019 an increase to 7 percent was expected. International Monetary Fund and Moody's expected growth rate to 7.3 percent and 7.5 percent in the fiscal years of 2019-2020 and 2020-2021, respectively. According to Goldman Sachs, India is going to overtake France and 
Italy by 2020 ; UK, Germany and Russia by 2025 , Japan by 2035 , and is going to be the third economic superpower only after the USA and China.

India's recent strong growth was supported by many factors like macroeconomic policies, new inflation framework, subsidy reforms, fiscal consolidation, quality of public expenditure, stable balance payment situation, recent policy reforms, monetary policy reviews, healthy foreign currency reserves, excellent flows of foreign direct investments, collaboration with foreign countries, improve credit behaviour, efficient financial institutions, conducive business environment, stable government and robust capital markets. India, pre-independence time's capital market was rarely existent and agriculture was the main contributor to the country's economy. Firms were very less in those days and the number of stocks traded in stock exchanges was even lesser. The gilt-edged market for government and semi-government securities dominated the Indian capital market. Retail investors were very less in and that too was restricted to the rich people from urban places. There were no specialized financial institutions and services to encourage the savings of the people and materialize them for investment. After independence, especially after 1991 liberalization, the Indian capital market has made tremendous improvement in all the sectors as reflected by increased companies \& their corporate announcements, different type of securities, financial institutions, intermediaries, stock exchange business, foreign direct \& indirect investments, volume of savings, investments and last but the least retail investors from all the classes of people.

In the period 2008-2017, in the very first week by January 2008, the Indian stock markets were on massive bullish trends especially on the 10th day when the benchmark index BSE SENSEX was recorded at 21,206.77 points, supported by domestic institutional investors and retail investors on expectations that India will remain one of the most reliable destinations to foreign institutional and domestic investors. By 21st January 2008, the market sentiment dramatically changed and the benchmark index BSE SENSEX experienced the most significant single day loss ever due to possible global financial crisis and that bear sentiment continued another one year till the markets recovered. In the year 2011 also, the markets started losing the value and this continued till the beginning of 2012 when the markets finally recovered and another bearish trend observed during the period 2015 -2016 also. During 2008 - 2017, Indian stock markets market capitalization increased from Rs. 50 lakh crores in 2008 to Rs. 150 lakh crores in 2018 almost a 3x time's growth in ten years.

Many factors, like the country's financial situation, currency fluctuation, crude oil fluctuation, trade wars, development of a country, etc., influence the world economic growth. The world economic growth affects the country's growth also because the economy now is a global factor. Growth of country's influence by along with the world economy and local factors also like political stability, currency stability, industry growth, financial institutions growth, investments, savings, stock market growth, corporate growth, and many more. Rise in the stock markets is influenced by domestic economic factors as well as global factors. An important thing to note is how stock markets influence corporate announcements and vice versa.

There is a need to undertake research on dividend announcements and their impact on stock prices due to the following reasons. At present, all the financial markets in the globe are interconnected to each other, and any government announcement in one country or a dividend announcement by a firm has a significant impact on the stock markets. In this context, it is a challenge to the mutual fund managers, institutional investors, high net worth investors, retail investors and others to forecast future returns and create better portfolio investments by understanding and evaluating different types of dividend announcements. Based on the positive or negative movements of stock prices, for a particular dividend announcement, as mentioned earlier, investors could decide whether to buy or sell a specific stock. Hence, there is a need to undertake a descriptive study on the impact of dividend announcements on stock prices so that the various investors and others would be benefited from the findings of the research and create better profitable investment portfolios.

A right dividend announcement by a firm but at the wrong time may cost the company to lose its stock value in the market. Hence, there is a need to undertake a study on determining the appropriate time (market trend) to announce dividend announcements to attract investors. Further, the firms are facing the agency problems with their dividend executives and the owners of the firm are keen to know whether the dividend announcements such as cash dividends, stock splits, stock dividends, and rights issues are the effective tools to handle this agency problem or not? Finally, the policymakers are facing the difficulties of describing the guidelines as to when to announce dividend announcements and what information is to be disclosed to the stakeholders in the market so that there could not be an adverse reannouncement to the dividend announcements of the firms. For the reasons mentioned above, there is a need to undertake a study on dividend announcements and their impact on stock prices in India.

The scope of the study is confined to study the impact of only dividend announcements and their impact on the market price of the stock. Further, the scope of the study is confined only to study the impact of dividend 
announcements on Indian stocks i.e., more particularly, the stocks listed in the BSE 500 Index. But the stocks listed on other stock markets like NSE, are not included in the study. There are several factors that affect the market price of a stock like nature of the industry, government support to a particular sector, international factors, and many more factors. But the study is restricted to study only the impact of dividend announcements on the market price of a specific stock.

An abnormal return narrates the unusual gains produced by specific stock or group of stocks over a period of time or a particular day. Abnormal returns may be positive or negative, finds risk-adjusted returns. Below and Johnson (1996), Ngoc and Cuong (2016), and Chavali and Nusratnnisa (2013) observed positive abnormal returns around dividend announcements, but Gunalp, Kadioglu and Kilic (2011), noted a significantly negative relationship between dividend announcement and stock price. Signaling is a theory that tells how the firm announcement of dividend announcement is a sign of positive or negative future earnings. This is the most researched area after abnormal returns. Gupta, Dogra, Vashisht and Ghai (2012), Dasilis (2007), and Elfakahani (1998) proved dividend announcements provide signals to the market. But, Chen, Nieh, Da Chen and Tang (2009), and Vieira and Rapos (2007) observed weak evidence for the signalling hypothesis. In semi-strong form of efficiency, the security prices reflect all publicly available information. This implies that an investor will not be able to outperform the market by analyzing the current company-related or other relevant information. Corporate announcements use one of the new information to measure the efficiency of the stock markets. Fama, Fisher, Jensen and Roll (1969), Chavali and Zahid (2011), Hua and Ramesh (2013), supported the efficient market hypothesis; which means that the market quickly adjusts to corporate announcements information. Although Gupta, Dogra, Vashisht and Ghai (2012), Dasilis (2007) do not support the efficient market hypothesis.

It is observed from the review of literature that researchers express contradict opinions on the impact of dividend announcements on stock prices in the world markets. Some of the studies proved that there exist positive abnormal returns around dividend announcements and some proved that the abnormal returns are negative. Furthermore, some studies showed that abnormal returns are statistically significant and some are statistically insignificant. Even in the case of Indian stocks, researchers have a different opinion about dividend announcement's effect on the stock price. Regarding Indian market efficiency, few studies have evidence that it is an efficient market and others proved that it is not so. Hence, the Existence of such diverse and contradictory opinions gives an immense opportunity to study the effect of dividend announcements on stock prices. Thus, this study tries to investigate on contradict results of various researches by using different factors like market size, rate of dividend announcement, and market trends.

The paper divides into second section review of literature, third section research methodology, fourth section data analysis and interpretation and fifth section is conclusion then and references.

\section{Review of Literature}

Kalay (1982) examined the ex-dividend day behaviour of stock prices by using the 2540 observations during 1962-1965 in USA markets. The author found a positive relationship between the price drop on ex-dividend date behaviour and corresponding dividend yield. The author concluded that share prices behaviour on ex-dividend day is not influenced by either tax effect or clientele effect. Litzenberger and Ramaswamy (1982) examined the cause of dividend effects on equity share prices is tax effect or information effect by using New York Stock Exchange stocks (NYSE), USA, during the period from 1940 to 1980. They found how equity share price returns and future dividend yields have a positive and non-linear relationship. The forecast rule for future dividends is purely on information that is accessible to the investor ex-ante. They concluded that significant dividend yield effects on equity share price returns could not be attached to the information content in the previous awareness that the company will announce a dividend of unknown immensity.

Asquith and Mullins Jr (1983) studied the dividend payment initiation impact on the wealth of shareholders in the USA stock market by observing 168 companies first dividend or initiation of the dividend during the period 1954-1963. They found more returns from dividend firms than any previous studies on dividends. The returns are positively associated with the size of the initial dividend payment. Their results support the subsequent increase of dividend may result in a more positive impact on the wealth of shareholders than the dividend initiation. They concluded that dividends convey distinctive and worthy information to investors from the results of first-time dividend and dividend initiation. John and Lang (1991) investigated insider trading around corporate dividend announcements in USA markets during 1975-1985. Their study based on the efficient equilibrium in a signalling model with endogenous insider trading. They found that abnormal returns are negative and significantly less for companies with insider selling before the dividend initiation announcement than the without insider trading companies or only insider buying companies. Authors concluded that insider trading is a 
signalling thing, combining with corporate dividend signals, it may be a helpful outlook to understand insider trading around dividend announcements and related price effects.

Below and Johnson (1996) investigated dividend increase, decrease announcements and information content hypothesis (ICH) on the stock market price changes in different market phases. Their sample consists of 2434 dividend increase announcements and 323 dividend decrease announcements of companies listing in NYSE / AMEX during the period from 1970 to 1982 . Authors divided the market trends into four periods, two bull markets and two bear markets, depending on the index movement. They found significant abnormal returns around dividend announcements in market trends. Dividend increase (good information) and dividend decrease (bad information) announcements have a significant impact on the market price of share in different market trends. Elfakahani (1998) examined the dividend signals expected favourableness, dividend change direction and dividend announcement signalling role. The sample contains 427 dividend announcements, 334 increases, and 93 decreases, during the period from 1976-1985. He proposed the dividend signal has three parts, first is dividend signal expected favourableness (good, bad or ambiguous), second is dividend change direction (positive or negative) and last is dividend signal role (confirmatory, clarificatory or unclear). The author found that dividend increase / decrease / no change announcements affect the market price of the stocks and also saw that the signalling role of dividend announcement has a considerable impact on the company's market price. The study concluded that in all three signalling factors, dividend signal expected favourableness becomes the influential factor.

Bessler and Nohel (1999) investigated the asymmetric information, dividend reductions and contagion effects in bank stock returns by using 17 banks' regular dividends during the period 1975 to 1981 . They used event methodology to calculate the abnormal returns and cumulative abnormal returns surrounding dividend announcement days. They tested the contagion effect presence in share returns associated with dividend announcements of money centre banks. They found that dividend decreases instigate the negative abnormal returns in the shares of non-announcing money centre banks. They concluded that contagion impacts appear consistent with informed rather than the contagious panic behaviour. Fama and French (2000) studied the disappearing dividends: changing firm characteristics or lower propensity to pay? They examined the company's listing in NYSE, AMEX, and NASDAQ during the period from 1963 to 1998 in US capital markets. In their analysis, they found that cash dividend-paying companies drastically reduced to $20.8 \%$ in 1999 from $66.5 \%$ in 1978 and also find that downfall because of changing features of public traded companies. The authors concluded that publicly listed companies moving profoundly towards small companies with less profitability and powerful growth opportunities.

Bandara and Samarakoon (2002) studied the Sri Lanka stock market to investigate the dividend announcement information content impact, dividend announcements by firm size effect, and dividend growth impact on stock prices. The sample contains 37 companies listing in Colombo stock exchange and study period from 1993 to 1998. They found significant dividend information impact on stock prices in the Sri Lanka equity market and also it is a positive impact in the market on an average. Small companies reacted strongly to dividend announcement information content and better dividend growth announcements. They also found that something different impact on stocks when companies were announcing lower dividend growth. Finally, concluded that the Sri Lankan stock market is an informationally efficient market to its inconsistent results. Brio (2004) studied the Spanish stock market to know the link between dividend payments and insider trading. The sample consists of 624 dividend announcements, 319 dividend increases, 219 dividend decreases, \& 82 no change announcements, from 83 non-financial companies listing in the Spanish market (SIBE) during the period from 1992-1996. He found that the Spanish stock market responds positively (negatively) to hike in dividends when dividend payments are fallow of insiders buy (sell). The author concluded that for the Spanish stock market, it is too simple guessing that increase in dividends announcement is always regarded as excellent news by the market.

Amihud and Li (2005) studied the impact of institutional holdings on dividend announcements and dividend announcement declining information content in the American stock market. Authors used the event methodology to explain the "disappearing dividend" phenomenon, and the sample size is 16,189 quarterly announced dividend events collect from American companies from 1962-2000. They proposed the two hypotheses in their study. One is the "disappearing dividend" phenomenon, and the second one is the institutional holding hypothesis. They found that market price reannouncement is a decreasing trend to dividend increase/decrease announcements in the late 70s and also finds that in high institutional holding firm stocks market price response to dividend announcement is less. Companies with a more institutional stake are less likely to increase their dividends. They concluded that disappearance dividends indicate the decreasing job of dividends as a means to convey information due to the institutional stake hike in companies. 
Dasilas (2007) examined the stock market reannouncement to dividend announcements in the Greek stock market. The author used the 216 dividend announcements from the period of 2000 to 2004 to check the market price of the stock and volume reannouncement to dividend change announcements. The dividend announcement day stocks abnormal returns are minimum at 0.324 percent and abnormal returns are above $1 \%$ for dividend increase announcements. The study concluded that the market price of the shares reacts significantly to dividend increase/decrease announcements and also supports the "information content of dividend hypothesis." Vieira and Raposo (2007) examined the European stock markets to understand the dividend increase or decrease announcement impact on market price returns. They investigated the classical beliefs of the dividend signalling hypothesis by using the data from three European countries, United Kingdom, France, and Portuguese. Their sample consists of 2662 dividend increases, 273 decreases \& 343 no change announcements from the UK, 235 increases, 62 decreases \& 59 no change dividend announcements from France during the period 1995-2002 and 158 increases, 121 decreases \& 101 no change dividend announcements from Portuguese market during the period 1989-2002. Their results do not carry the positive connection between the dividend increase/decrease announcements and the stock price changes for French companies. For Portuguese and UK companies, it is a weak positive connection between the dividend increase/decrease announcements and the stock price changes.

Blau, Fuller, and Ness (2009) investigated the short-selling surround announcement of dividend date and ex-dividend dates by using 777 New York Stock Exchange (NYSE) listed companies. They used the quarterly dividend announcement data and data period belongs to 2005 and 2006. Before the dividend announcement increases (decreases), they did not find any irregular less (more) short-selling. But they found that before the adverse announcement of dividends short-selling task is less lucrative than short-selling task surround non-event time. They also found that after the ex-dividend day, short-selling activity is a high return activity. Finally, the authors concluded that for the short-sellers announcement of dividends does not give any lucrative trading chances. Chen, Nieh, Da Chen, and Tang (2009) investigated the A-share companies in the China equity market from 2000 to 2004 by using the event methodology to determine the impact of cash dividend changes and also to investigate the Chinese share markets holds the signalling hypothesis or not. The sample contains 460 companies with cash dividend increase announcements and 422 companies with cash dividend decrease announcements from Shanghai stock exchange and Shenzhen stock exchange. They found that the Chinese stock market reacted positively to cash dividend changes announcement, but partially support the signalling hypothesis of dividends.

Gunalp, Kadioglu, and Kilic (2011) examined the impact of cash dividend announcement on the market price of the share in Turkish capital markets. They analyzed the abnormal returns that surround the dividend announcement date by using event study methodology. Authors pick the 429 cash dividend announcement events from 80 firms from 2003 to 2009. They find that abnormal returns after the announcement and cash dividends per share have a significant negative connection and also their research evidence holds the tax clientele effect hypothesis. The inefficiency of the Turkish capital markets reduced over time and according to their study, share price adjustment begins at event day only, whereas the remarkable price adjustment happens between event day and second day after the event. Hussainey, MGBAME, and MGBAME (2011) investigate the connection between stock price changes and dividend policy in the United Kingdom stock market. Multiple regression model and ten years of data from 1998 to 2007 used to test the relationship between dividend policy and stock price reannouncement. They found that stock price reannouncement is positive to dividend yield and stock price reannouncement is contrary to dividend pay-out ratio. The more dividend pay-out means minimal variability, a share price would be at and the dividend pay-out ratio is an essential cause of variability of the share price. They also found that the company's growth rate, debt level, size, and earnings cause the share price changes.

Gupta, Dogra, Vashisht, and Ghai (2012) investigated the stock price reannouncement to dividend announcement in the Indian stock market. They choose the sample of 65 dividend announcements that happen from 2006 to 2009 from 28 firms listed in BSE SENSEX. Event methodology used to know abnormality of stock price returns around dividend announcements. They found that share prices respond positively to dividend increase announcements and also found that announcement of dividend holds the signalling hypotheses. They concluded from their study that; Indian stock market is not efficient. Chavali and Nusratunnisa (2013) studied the Indian stock market to find the announcement of dividend impact on the stock price returns. They picked the 67 dividend announcements from the fast-moving consumer goods industry (FMCG), which happens during the 2007 to 2011 period. Authors used the event methodology to calculate stock's abnormal returns around dividend announcement dates and also use the 41 days event window. They found that stock price abnormal returns are positive and results are statistically significant around dividend announcement days.

Berdnikova and Rogova (2014) examined the Russian firms' market price reannouncement towards the announcement of dividends. They analyzed the market price reannouncement towards dividend announcements 
in different sectors. The sample consists of 115 dividend announcements from Russian public firms and sample announcements occur from 2009 to 2013. The event methodology model is used to calculate the abnormal return movements around dividend announcement dates. They found that market price reacts opposite to dividend change announcements like if dividend change announcements are good, share price and market capitalizations response opposite to this news and if dividend change announcement is bad, market price and market value of the share react positively to this news. Ngoc and Cuong (2016) examined the dividend announcements date and ex-dividend announcement date effect on share price returns in the Vietnam stock market. Their sample size is 1962 events from 432 companies listed in the Vietnam stock market and research period from 2008 to 2015. They used the event study methodology to calculate the abnormal returns around the dividend announcement date and ex-dividend announcement date. They found positive abnormal returns surrounding the dividend announcement date and also observed an upward movement trend in share price till ex-dividend date approaches and then a downward trend from ex-dividend date.

\subsection{Research Gaps}

- Size effect or market capitalization effects have not been explored much into dividend announcements in India, so it is a gap to examine the relationship between market capitalization effect and dividend announcements.

- The rate of dividend announcements impacts on stocks not explored much in India, so it is a gap to study the rate of dividend announcements impact on stock returns.

\section{Research Methodology}

\subsection{Objectives of the Study}

From the above discussion, the study is undertaken with the following objectives.

- To examine whether the impact of dividend announcements on stock prices varies with a market capitalization of the company or not?

- To assess whether the impact of dividend announcements on stock prices varies with the rate of dividend announcement or not?

\subsection{Research Hypotheses}

The following hypotheses are posited to test while researching this study. They are grouped under the following heads.

- $\mathrm{H} 1_{0}$ : There is no significant impact of dividend announcements by market capitalization wise on the stocks in India

- $\quad \mathrm{H} 2_{0}$ : There is no significant impact of different rate of dividend announcements by market capitalization wise on the stocks in India

\subsection{Data Collection}

The period for this study is from 2008 - 17, which is the period witnessed significant fluctuations in the Indian stock market. During this period, stocks went from high level to low level and low level to high level two to three times. Many stock exchanges are operating in India, but only two, namely the Bombay Stock Exchange (BSE) and National Stock Exchange, are the major exchanges that operate at the national level. BSE is one of the oldest stock exchanges and a greater number of companies are listed exchange in India. BSE has been selected for the representation of the Indian Stock Market for the selection of dividend announcements and identification of the companies. Stock price information collected from BSE website, dividend announcement information collets from moneycontrol.com, capitalmarkets.com, and data cross-check with BSE website.

\subsection{Sampling Procedure \& Sample Selection}

Non-probability sampling technique (judgement sampling) used for the selection of the companies for this study. Sample events selected form S\&P BSE 500 companies only because S\&P BSE 500 is a broader index and index constitutes $90 \%$ above the capitalization of the total market capitalization. BSE Large-cap, BSE Mid-cap, and BSE small-cap indexes used to segregate the sample into market capitalization wise. BSE stock exchange regularly reconstitutes the indexes based on market capitalization wise of the companies, so it makes it challenging to select the sample for the study. Hence market capitalization base has taken companies which are there in January 2018 BSE indexes list only. 


\subsubsection{Dividend Announcements Selection}

Two assumptions assumed for the selected samples for dividend announcement. First, the minimum investor preference of dividend is 10 percent. The second one is that the announcement of dividend is compulsory every year because it gives to measure the dividend impact in different market trends from the same company samples.

1. In the first step, total dividend announcements considered which announced during the research period.

2. The second step in a year if any company announced dividends more than one time, then taken only one dividend (preference given final dividend if not highest percentage interim dividend picked) and excluded other dividend announcements for study.

3. In the third step, samples only included $10 \%$ and above dividend announcements.

4. In step four, identification of companies that have paid dividends regularly every year throughout the research period.

5. In step five, only S\&P BSE 500 index companies selected form step four companies.

6. In steps 6,7 , and 8 large-cap, mid-cap, and small-cap companies selected from S \& P BSE 500 companies chosen from step five.

7. Selection of samples for dividend announcements shows in the following tables

Table 1. Summarizes the step wise selection of dividend announcements

\begin{tabular}{|c|c|c|c|c|c|c|c|c|c|c|c|c|}
\hline Steps & Year & 2008 & 2009 & 2010 & 2011 & 2012 & 2013 & 2014 & 2015 & 2016 & 2017 & $\begin{array}{l}\text { Total No of } \\
\text { Dividend } \\
\text { announcements }\end{array}$ \\
\hline Step 1 & $\begin{array}{l}\text { Total Dividend } \\
\text { Announcements During } \\
\text { Research period by the } \\
\text { year wise }\end{array}$ & 1697 & 1531 & 1782 & 1767 & 1642 & 1646 & 1609 & 1529 & 1564 & 1081 & 15848 \\
\hline Step 2 & $\begin{array}{l}\text { Only one dividend } \\
\text { announcement for each } \\
\text { company (if multiple } \\
\text { announcements are } \\
\text { there in a year) is taken } \\
\text { from above events (First } \\
\text { preference is Final } \\
\text { Dividend) }\end{array}$ & 1517 & 1357 & 1545 & 1549 & 1409 & 1396 & 1290 & 1270 & 1221 & 932 & 13486 \\
\hline Step 3 & $\begin{array}{l}\text { Number of } \\
\text { announcements where } \\
\text { rate of dividend } \\
\text { declared is minimum } \\
10 \% \text { and above }\end{array}$ & 1316 & 1157 & 1305 & 1328 & 1186 & 1158 & 1093 & 1073 & 1021 & 836 & 11473 \\
\hline Step 4 & $\begin{array}{l}\text { Number of companies } \\
\text { declared dividend } \\
\text { announcements every } \\
\text { year from step } 3 \text { sample }\end{array}$ & $449 \mathrm{Cc}$ & mpanies & & & & & & & & & 4490 \\
\hline Step 5 & $\begin{array}{l}\text { Number of S\&P BSE } \\
500 \text { companies who } \\
\text { declared dividend every } \\
\text { year from step } 4 \text { sample }\end{array}$ & $235 \mathrm{Cc}$ & mpanies & & & & & & & & & 2350 \\
\hline Step 6 & $\begin{array}{l}\text { Number of BSE } \\
\text { Large-cap Companies } \\
\text { step 5 sample }\end{array}$ & $59 \mathrm{Cor}$ & apanies & & & & & & & & & 590 \\
\hline Step 7 & $\begin{array}{l}\text { Number of BSE } \\
\text { Mid-cap Companies } \\
\text { from step } 5 \text { sample }\end{array}$ & $53 \mathrm{Cor}$ & apanies & & & & & & & & & 530 \\
\hline Step 8 & $\begin{array}{l}\text { Number of } \quad \text { BSE } \\
\text { Small-cap companies } \\
\text { from step } 5 \text { sample }\end{array}$ & $123 \mathrm{Cc}$ & mpanies & & & & & & & & & 1230 \\
\hline \multicolumn{2}{|c|}{ Total Sample selected } & $235 \mathrm{Cc}$ & mpanies & & & & & & & & & 2350 \\
\hline
\end{tabular}

Source. bseindia.com and moneycontrol.com. 
Table 2. Break-up of the different dividend announcements based on different market capitalization wise

\begin{tabular}{|c|c|c|c|c|c|c|c|c|}
\hline $\begin{array}{l}\text { Type of } \\
\text { Capitalization }\end{array}$ & $\begin{array}{l}\text { Final } \\
\text { Dividend }\end{array}$ & $\begin{array}{l}\text { Interim } \\
\text { Dividend }\end{array}$ & $\begin{array}{l}\text { Dividend } \\
\text { with Bonus }\end{array}$ & $\begin{array}{l}\text { Dividend } \\
\text { with Split }\end{array}$ & $\begin{array}{l}\text { Dividend } \\
\text { with Bonus } \\
\& \text { Split }\end{array}$ & $\begin{array}{l}\text { Clash } \\
\text { with } \\
\text { Others } \\
\text { events }\end{array}$ & $\begin{array}{l}\text { Price info } \\
\text { missing* }\end{array}$ & Total \\
\hline Large & 492 & 35 & 20 & 8 & 2 & 3 & 30 & 590 \\
\hline Mid-cap & 425 & 42 & 12 & 6 & 1 & 4 & 40 & 530 \\
\hline Small & 838 & 66 & 6 & 12 & 1 & 17 & 290 & 1230 \\
\hline Total & 1755 & 143 & 38 & 26 & 4 & 24 & 360 & 2350 \\
\hline
\end{tabular}

Notes. * 3 large, 4 mid-cap and 29 small companies are not traded some days during research a period,

Source: Author's Calculations.

\subsubsection{Final dividend Announcement Classification Based on Dividend Percentage}

Firms announce dividend rates generally range from 0.5 percent to around 3000 percent. From the process of dividend sample selection, it observes that a more popular dividend ranges from 10 percent to 500 percent. Dividend rate classification happened based on two reasons, first is based on observation of dividend rates during the ten years research period, i.e., which dividend rate announcement is more. The second one is purely based on the assumption that investors' psychological reactions to a particular dividend rate. In the process of classification of dividend rate, stocks face value not considered. Based on the above reasons final dividend rate classified and presented in the following table.

Table 3. Classification of final dividend rate action based on market capitalization

\begin{tabular}{llcccc}
\hline \multicolumn{1}{c}{ S. No } & Range of dividend rate classification Large-cap & Mid-cap & Small-cap Total \\
\hline Classification $110 \%$ to $49 \%$ & 33 & 68 & 301 & 402 \\
Classification $250 \%$ to $99 \%$ & 89 & 112 & 272 & 473 \\
Classification $3100 \%$ to $199 \%$ & 152 & 132 & 148 & 432 \\
Classification 4 & $200 \%$ to $499 \%$ & 153 & 84 & 111 & 348 \\
Classification $5500 \%$ to $999 \%$ & 44 & 25 & 6 & 75 \\
Classification $61000 \%$ and above & 21 & 4 & 0 & 25 \\
Total & 492 & 425 & 838 & 1755 \\
\hline
\end{tabular}

Source. bseindia.com and moneycontrol.com.

Table 3 says that small-cap actions are high in the lower range of dividend classifications, and large-cap actions are less in the lower range of classification. Contrary to that, large-cap actions are more in a higher range and small-cap actions are less in a higher range. Mid-cap actions are middle in both ranges. In the 1000 percent and above range, small-cap actions are nil.

\subsubsection{Event Window Selection}

India being a developing country with an evolving capital market, it is characterized by volatility in short period. The transparency of the dividend world is questionable and there appears to be large scale insider trading before the announcement of any event. Therefore, the researcher has chosen 61 days as the event window for the study on the impact of dividend announcements on the stock market. This 61-day event window, which is defined 0 -days (the date on which event is publicly announced) and -30 to +30 days (the date 30 days previous from the event date and 30 days post event dates) for the study. The efficiency of the market analyses by using CAAR (Cumulative Average Abnormal Returns) in different window periods, such as 61 days, 41 days, 21 days, 11 days, 5 days, and 3 days. This study is associated with the stock price behaviour surrounding the announcement date and therefore labelled as an event study. The methodology of an event study is associated with the Efficient Market Hypothesis developed by E. F. Fama (1970), to understand the adjustment of stock prices to new information. The methodology is commonly referred to as Fama Fisher Jensen and Ross (1969) methodology of an event study.

The steps followed to study the events are as follows:

Step1: Identify the events to be studied and pinpoint the date $(\mathrm{t}=0)$ on which the events are announced. 
Step2: Decide on the event window (ensure that during this period, no other important event has been announced). The event window dividend announcement as $\mathrm{t}=0$ (Event date) and a period of -30 days previous to the event date and +30 days after the event date, which is shown below with the help of the graph.

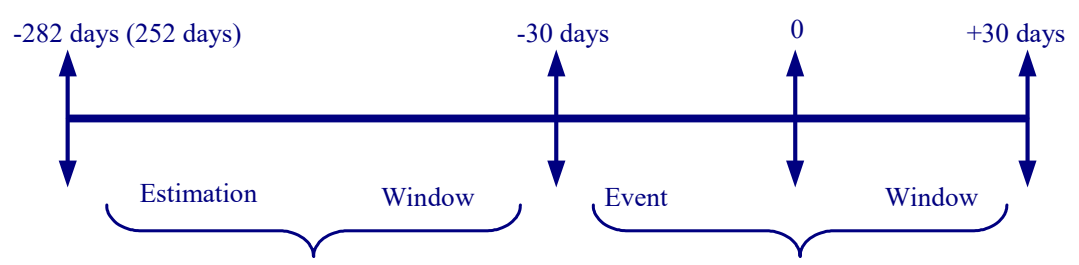

In this figure, $\mathrm{t}=0$ is shown as event announcement date and the respective effect of this announcement on share prices is calculated for the period of -30 days to +30 days to know if there is any impact of such announcement and for how many days it persists. The estimation window will be -282 days to -30 days of the event day window to regress the stock and index.

\subsubsection{Tools Used for the Study}

ADF test to know the stationery of time series data, Market model for event study, Alpha coefficient, Beta coefficient, Descriptive statistics - Max, Min, Mean, Median and Standard deviation, Abnormal returns, Average abnormal returns, Cumulative average abnormal returns and Paired t test Market Model as fallows:

$$
\text { Expected Return }(\mathrm{E})=\alpha+\beta \mathrm{R}_{\mathrm{M}}
$$

$\alpha=$ Alpha coefficient of security with Index;

$\beta=$ Beta coefficient of the security with Index

$\mathrm{R}_{\mathrm{M}}=$ Expected of the return of the Index

Abnormal returns calculated as fallows

$\mathrm{AR}=\mathrm{R}-\mathrm{E}$

$\mathrm{R}=$ Actual Returns; $\mathrm{AR}=$ Abnormal returns

Average Abnormal returns calculated as fallows

$$
\mathrm{AAR}=\frac{\sum_{t=1}^{n} A t}{n}
$$

$\mathrm{t}=$ the number of securities in the study; $\mathrm{n}=$ total number of stocks in the class

$t$ test used to determine the significance of abnormal returns

$$
t=\frac{A A R}{\sigma(A A R)}
$$

$A A R=$ Average abnormal return;

$\sigma(A A R)=$ Standard error of average abnormal return;

Standard error is calculated is $(\mathrm{AA} R)=\frac{\sigma}{\sqrt{n}}$

\section{Data Analysis and Interpretation}

\subsection{Classification 1: Final Dividend Actions Rate 10 Percent to 49 Percent}

Table 4. Abnormal returns descriptive statistics of final dividend rate 10 percent to 49 percent on event day

\begin{tabular}{llllllll}
\hline \multirow{2}{*}{ S. No } & \multirow{2}{*}{ Sample details } & \multirow{2}{*}{$\mathrm{N}$} & \multicolumn{5}{c}{ Descriptive statistics of abnormal returns (\%) } \\
\cline { 4 - 8 } & & & Max & Min & Mean & Median & SD \\
\hline 4.1 .1 & Full sample & 402 & 19.431 & -16.275 & 0.258 & -0.038 & 4.637 \\
4.1 .2 & Large-cap & 33 & 13.781 & -9.230 & -0.200 & 0.016 & 4.436 \\
4.1 .3 & Mid-cap & 68 & 19.222 & -9.167 & 0.553 & 0.151 & 4.783 \\
4.1 .4 & Small-cap & 301 & 19.431 & -16.275 & 0.241 & -0.116 & 4.636 \\
\hline
\end{tabular}

Source. Author's calculations by using stock prices from bseindia.com. 
It is observed from above table 4 that more samples from small-cap because lowest final dividend rate 10 to $49 \%$ announces by generally small-cap companies only. Highest positive maximum return and most moderate negative minimum returns observe in small-cap final dividend announcement 10 percent to 49 percent rate on event day abnormal returns. Small-cap abnormal returns range is high, and the large-cap returns range is less. Mean of full sample, mid-cap, and small-cap abnormal returns on event day are positive, and large-cap mean in negative. Median of full sample and small-cap abnormal returns on event day are negative, but large-cap and mid-cap medians are in positive, and median of all observations is lower than their respective mean values. The deviation of abnormal returns in most of the observations is almost the same, but mid-cap abnormal returns deviation is a little bit higher than other observations and as unusual small-cap deviation little bit lower than other observations. It can be interpreted from the above discussion and table that higher maximum return in full sample and small-cap final dividend announcement, small-cap mean values lead to all-cap mean into positive value on the event day.

Table 5. Event Day results for final dividend announcements rate 10 percent to 49 percent by market capitalization wise

\begin{tabular}{lllllll}
\hline \multirow{2}{*}{ S. No } & \multirow{2}{*}{ Sample Details } & \multicolumn{2}{l}{ Event day results } \\
\cline { 3 - 7 } & & AAR $(\%)$ & CAAR $(\%)$ & AAR t Stat & p Value & AAR Significance \\
\hline 4.1 .1 & Full sample & 0.258 & 4.016 & 1.115 & 0.265 & Not Significant \\
4.1 .2 & Large-cap & -0.200 & 2.165 & -0.259 & 0.798 & Not Significant \\
4.1 .3 & Mid-cap & 0.553 & 3.104 & 0.954 & 0.343 & Not Significant \\
4.1 .4 & Small-cap & 0.241 & 4.425 & 0.903 & 0.367 & Not Significant \\
\hline
\end{tabular}

Source. Author's calculations by using stock prices from bseindia.com.

Note. $*$ significance at $5 \%$ level.

From the above table 5, it can understand that full sample, mid-cap, and small-cap final dividend announcements 10 percent to 49 percent rate abnormal returns are positive and large-cap final dividend announcement average returns are in negative on the event day. All average abnormal returns are much higher in mid-cap final dividend announcement; it means mid-caps are reacting more positively to the lower percent final dividend rate. Cumulative average abnormal returns also positive and higher in all observations, and it is very high in small-cap on event day. The calculated p-value is higher than 0.05 value in full sample, large-cap, mid-cap, and small-cap final dividend announcement, so it means at a 5 percent level of significance null hypothesis is not rejected. It can be interpreted that full sample, large-cap, mid-cap, and small-cap final dividend 10 percent to 49 percent rate announcement do not impact on the stock prices at 5 percent level significance.

\subsection{Classification 2: Final dividend Announcements Rate 50 Percent to 99 Percent}

Table 6. Abnormal returns descriptive statistics of final dividend rate 50 percent to 99 percent on event day

\begin{tabular}{llllllll}
\hline \multirow{2}{*}{ S. No } & \multirow{2}{*}{ Sample details } & \multirow{2}{*}{$\mathrm{N}$} & \multicolumn{5}{c}{ Descriptive statistics of abnormal returns (\%) } \\
\cline { 4 - 8 } & & & Max & Min & Mean & Median & SD \\
\hline 4.2 .1 & Full sample & 473 & 19.321 & -10.793 & 0.155 & -0.146 & 3.518 \\
4.2 .2 & Large-cap & 89 & 7.494 & -5.812 & 0.267 & 0.010 & 2.496 \\
4.2 .3 & Mid-cap & 112 & 13.377 & -9.392 & 0.014 & -0.104 & 3.111 \\
4.2 .4 & Small-cap & 272 & 19.321 & -10.793 & 0.176 & -0.260 & 3.944 \\
\hline
\end{tabular}

Source. Author's calculations by using stock prices from bseindia.com.

From above table 6, it can be said that maximum sample size is from small companies in a 50 percent to 99 percent final dividend rate. The highest positive maximum return observed in small-cap final dividend announcement and least minimum negative return found in small-cap final dividend announcement abnormal returns on the event day. Small-cap abnormal returns range is high, and the large-cap returns range is less. Full sample final dividend announcement maximum return comes from small-cap and minimum return also comes from small abnormal returns on the event day. Mean of full sample, large-cap, mid-cap, and small-cap abnormal returns on event day are positive, mainly mid-cap mean is low, and large-cap mean is high. Median of full sample, mid-cap, and small-cap stocks abnormal returns in negative and median of all observations are smaller 
than their respective mean values, and the small-cap median is a little bit away from its mean. The deviation of abnormal returns is lowest in large-cap and highest in small-cap stocks abnormal returns.

Table 7. Event Day results for final dividend announcements rate 50 percent to 99 percent by market capitalization wise

\begin{tabular}{llccccc}
\hline \multirow{2}{*}{ S. No } & \multirow{2}{*}{ Sample Details } & \multicolumn{5}{c}{ Event day results } \\
& & AAR (\%) & CAAR (\%) & AAR t Stat & $\mathrm{p}$ Value & AAR Significance \\
\cline { 3 - 7 } 4.2 .1 & Full sample & 0.155 & 1.886 & 0.956 & 0.339 & Not Significant \\
4.2 .2 & Large-cap & 0.267 & 0.820 & 1.010 & 0.315 & Not Significant \\
4.2 .3 & Mid-cap & 0.014 & 1.604 & 0.047 & 0.963 & Not Significant \\
4.2 .4 & Small-cap & 0.176 & 2.351 & 0.735 & 0.463 & Not Significant \\
\hline
\end{tabular}

Source. Author's calculations by using stock prices from bseindia.com.

Note. * significance at $5 \%$ level.

From the above table 7 , it can be observed that full sample, large mid-cap and small-cap final dividend announcements 50 percent to 99 percent rate abnormal returns are in positive on event day, but the mid-cap average abnormal return is very close to zero percent. Cumulative average abnormal returns positive in all observations, and it is high in small-cap announcement on event day. Calculated p values are much higher than 0.05 value in all final dividend announcements, so it means, at a 5 percent significance level null hypothesis is not rejected. It can be interpreted that all final dividend 50 percent to 99 percent rate announcements does not impact the stock prices at a 5 percent level significance.

\subsection{Classification 3: Final Dividend Announcements Rate 100 Percent to 199 Percent}

Table 8. Abnormal returns descriptive statistics of final dividend rate 100 percent to 199 percent on event day.

\begin{tabular}{llcccccc}
\hline \multirow{2}{*}{ S. No } & \multirow{2}{*}{ Sample details } & \multirow{N}{*}{$\mathrm{N}$} & \multicolumn{5}{c}{ Descriptive statistics of abnormal returns (\%) } \\
\cline { 4 - 8 } & & Max & Min & Mean & Median & SD \\
\hline 4.3 .1 & Full sample & 432 & 14.298 & -8.417 & 0.330 & -0.139 & 3.344 \\
4.3 .2 & Large-cap & 152 & 11.495 & -5.938 & 0.056 & -0.283 & 2.813 \\
4.3 .3 & Mid-cap & 132 & 13.947 & -7.622 & 0.067 & -0.223 & 3.268 \\
4.3 .4 & Small-cap & 148 & 14.298 & -8.417 & 0.847 & 0.209 & 3.837 \\
\hline
\end{tabular}

Source: Author's calculations by using stock prices from bseindia.com.

From above table 8, it can be interpreted that in 100 percent to 199 percent final dividend rate, more samples come from large-cap final dividend announcement, and this classification has the highest number of samples compared to other classifications. Highest positive maximum return and lowest minimum negative return observed in small-cap final dividend announcement on the event day. The range of abnormal returns is high in small-cap and low in large-cap returns. Mean of all observation abnormal returns on event day are positive, but large-cap and mid-cap returns slightly equal to zero percentage. Median of all observations are negative except small-cap and also median of all observations is lower than their respective mean values. Small-cap deviation of abnormal returns is highest in this classification also and lowest in large-cap final dividend announcement. It can be interpreted from the above discussion and table that small-cap values may influence on full sample values because small-cap samples average abnormal return is high compare to other observations. 
Table 9. Event Day results for final dividend announcements rate 100 percent to 199 percent by market capitalization wise

\begin{tabular}{llccccc}
\hline \multirow{2}{*}{ S. No } & \multirow{2}{*}{ Sample Details } & \multicolumn{5}{c}{ Event day results } \\
\cline { 3 - 7 } & & AAR (\%) & CAAR (\%) & AAR t Stat & p Value & AAR Significance \\
\hline 4.3 .1 & Full sample & $0.331^{*}$ & 2.458 & 2.053 & 0.041 & Significant \\
4.3 .2 & Large-cap & 0.056 & 0.539 & 0.245 & 0.807 & Not Significant \\
4.3 .3 & Mid-cap & 0.067 & 2.646 & 0.234 & 0.815 & Not Significant \\
4.3 .4 & Small-cap & $0.847^{*}$ & 4.262 & 2.687 & 0.008 & Significant \\
\hline
\end{tabular}

Source. Author's calculations by using stock prices from bseindia.com.

Note.*significance@5\% level

From the above table 9, it can be analysed that full sample, large-cap, mid-cap, and small-cap final dividend announcements 100 percent to 199 percent rate abnormal returns are positive, but most of returns are very close to zero percent except small-cap returns. Cumulative average abnormal returns are also positive and higher in small-cap on the event day. In full sample and small-cap observations, calculated $\mathrm{p}$ values are lower than the 0.05, so it means that final dividend 100 percent to 199 percent rate announcements impact the stock price at a 5 percent level of significance in full sample and small-cap observations. In large-cap and mid-cap observations, calculated $\mathrm{p}$ values are higher than the 0.05 , so it means that the final dividend 100 percent to 199 percent rate announcements do not impact on the stock price at a 5 percent level of significance in large-cap and mid-cap observations. It can be interpreted that full sample and small-cap final dividend 100 percent to 199 percent rate announcements impact the stock prices at 5 percent level significance, and other announcements are not significant.

\subsection{Classification 4: Final Dividend Announcements Rate 200 Percent to 499 Percent}

Table 10. Abnormal returns descriptive statistics of final dividend rate 200 percent to 499 percent on event day

\begin{tabular}{llcccccc}
\hline \multirow{2}{*}{ S. No } & \multirow{2}{*}{ Sample details } & \multirow{2}{*}{$\mathrm{N}$} & \multicolumn{5}{c}{ Descriptive statistics of abnormal returns (\%) } \\
\cline { 4 - 8 } & & & Max & Min & Mean & Median & SD \\
\hline 4.4 .1 & Full sample & 348 & 10.853 & -10.209 & 0.112 & 0.067 & 3.118 \\
4.4 .2 & Large-cap & 153 & 8.687 & -8.903 & -0.13 & -0.282 & 3.056 \\
4.4 .3 & Mid-cap & 84 & 8.456 & -6.858 & 0.328 & 0.191 & 2.948 \\
4.4 .4 & Small-cap & 111 & 10.853 & -10.209 & 0.280 & 0.210 & 3.326 \\
\hline
\end{tabular}

Source: Author's calculations by using stock prices from bseindia.com.

Above table 10 explains that in a 200 percent to 499 percent final dividend rate, more samples again come from large-cap final dividend announcement. Highest positive maximum return and lowest minimum negative return observes in small-cap final dividend announcement on the event day. The range of abnormal returns is high in small-cap and low in mid-cap returns. Mean and median of full sample, mid-cap, and small-cap stock abnormal returns on event day are positive, but large-cap mean and median are in negative. Median of all observations is close to their respective mean values, and it means that values are not dragged either side much. Small-cap deviation of abnormal returns is highest in this classification also and lowest in mid-cap final dividend announcement, but average abnormal returns highest in mid-cap compare to other average abnormal returns.

Table 11. Event Day results for final dividend announcements rate 200 percent to 499 percent by market capitalization wise

\begin{tabular}{llccccc}
\hline \multirow{2}{*}{ S. No } & \multirow{2}{*}{ Null Hypothesis } & \multicolumn{5}{c}{ Event day results } \\
\cline { 3 - 7 } & & AAR (\%) & CAAR (\%) & AAR t Stat & $\mathrm{p}$ Value & AAR Significance \\
\hline 4.4 .1 & Full sample & 0.112 & 0.037 & 0.667 & 0.505 & Not Significant \\
4.4 .2 & Large-cap & -0.129 & -0.527 & -0.526 & 0.600 & Not Significant \\
4.4 .3 & Mid-cap & 0.328 & 0.087 & 1.019 & 0.311 & Not Significant \\
4.4 .4 & Small-cap & 0.281 & 0.775 & 0.888 & 0.376 & Not Significant \\
\hline
\end{tabular}

Source: Author's calculations by using stock prices from bseindia.com.

Note: * significance at $5 \%$ level. 
From the above table 11, it can be analysed that full sample, mid-cap, and small-cap final dividend announcements 200 percent to 499 percent rate abnormal returns are positive, but large-cap final dividend announcement returns are in negative. Cumulative average abnormal returns in large-cap are slightly negative, but in full sample, mid-cap and small-cap CAAR are positive, and in all announcements, returns are less than one percent. Calculated $\mathrm{p}$ values are much higher than 0.05 value in all final dividend announcements, so it means at a 5 percent significance level null hypothesis is not rejected. It can be interpreted that all final dividend 200 percent to 499 percent rate announcements does not impact the stock prices at a 5 percent level significance.

\subsection{Classification 5: Final Dividend Announcements Rate 500 Percent to 999 Percent}

Table 12. Abnormal returns descriptive statistics of final dividend rate 500 percent to 999 percent on event day

\begin{tabular}{llcccccc}
\hline \multirow{2}{*}{ S. No } & \multirow{2}{*}{ Sample details } & \multirow{2}{*}{$\mathrm{N}$} & \multicolumn{5}{c}{ Descriptive statistics of abnormal returns (\%) } \\
\cline { 4 - 8 } & & Max & Min & Mean & Median & SD \\
\hline 4.5 .1 & Full sample & 75 & 7.556 & -20.793 & 0.090 & 0.503 & 3.795 \\
4.5 .2 & Large-cap & 44 & 6.912 & -20.793 & 0.120 & 0.692 & 4.486 \\
4.5 .3 & Mid-cap & 25 & 7.556 & -8.337 & 0.130 & -0.002 & 2.681 \\
4.5 .4 & Small-cap & 6 & \multicolumn{5}{c}{ Sufficient events not available } \\
\hline
\end{tabular}

Source: Author's calculations by using stock prices from bseindia.com

Above table 12 says that in 500 percent to 999 percent final dividend rate classification has very fewer samples compare to other classifications and again, more samples come from large-cap final dividend announcement, and the important thing is that this classification is not having sufficient samples from small-cap companies. Highest positive maximum return in mid-cap final dividend announcement and lowest minimum negative return observes in large-cap final dividend announcement on the event day. The range of abnormal returns is high in large-cap and low in mid-cap returns. Mean and median of all observation abnormal returns on event day are positive and surprisingly median of full sample, and large-cap observations are higher than their respective mean values, but the mid-cap median is slightly in negative. The large-cap deviation of abnormal returns is highest in this classification and very lowest in mid-cap final dividend announcement. It can be interpreted from the above discussion and table that large-cap values may influence on full sample values because of large-cap samples high in total samples.

Table 13. Event Day for final dividend announcements rate 500 percent to 999 percent by market capitalization wise

\begin{tabular}{|c|c|c|c|c|c|c|}
\hline \multirow{2}{*}{ S. No } & \multirow{2}{*}{ Sample Details } & \multicolumn{5}{|c|}{ Event day results } \\
\hline & & AAR $(\%)$ & CAAR (\%) & AAR t Stat & $\mathrm{p}$ Value & AAR Significance \\
\hline 4.5 .1 & Full sample & 0.089 & -1.484 & 0.204 & 0.838 & Not Significant \\
\hline 4.5 .2 & Large-cap & 0.120 & -0.713 & 0.177 & 0.860 & Not Significant \\
\hline 4.5 .3 & Mid-cap & 0.130 & -2.267 & 0.242 & 0.811 & Not Significant \\
\hline 4.5.4 & Small-cap & \multicolumn{5}{|c|}{ Sufficient events are not available } \\
\hline
\end{tabular}

Source: Author's calculations by using stock prices from bseindia.com.

Note: * significance at $5 \%$ level.

From the above table 13, it can be analysed that full sample, large-cap, and mid-cap dividend announcements 500 percent to 999 percent rate average abnormal returns are in positive. Small-cap final dividend announcement samples are not sufficient to test the returns. Cumulative average abnormal returns in full sample, large-cap and mid-cap negative and in mid-cap returns are very lowest. Calculated $p$ values are higher than 0.05 value in all final dividend announcements, so it means at a 5 percent significance level null hypothesis is not rejected. It can be interpreted that all final dividend 500 percent to 999 percent rate announcements does not impact the stock prices at a 5 percent level significance. 


\subsection{Classification 6: Final Dividend Announcements Rate 1000 Percent and Above}

Table 14. Abnormal returns descriptive statistics of final dividend rate 1000 percent and above on event day

\begin{tabular}{llllllll}
\hline \multirow{2}{*}{ S. No } & \multirow{2}{*}{ Sample details } & \multirow{2}{*}{ N } & \multicolumn{5}{c}{ Descriptive statistics of abnormal returns (\%) } \\
\cline { 4 - 7 } & & & Max & Min & Mean & Median & SD \\
\hline 4.6 .1 & Full sample & 25 & 4.148 & -4.107 & -0.364 & -0.547 & 2.071 \\
4.6 .2 & Large-cap & 21 & 4.148 & -3.289 & -0.428 & -0.862 & 1.922 \\
4.6 .3 & Mid-cap & 4 & \multicolumn{6}{l}{ Sufficient events are not available } \\
4.6 .4 & Small-cap & 0 & No events & \\
\hline
\end{tabular}

Source: Author's calculations by using stock prices from bseindia.com.

Above table 14 explains that in 1000 percent above final dividend rate classification has very fewer samples compared to other classifications and again, most samples come from large-cap final dividend announcement. The important thing is that this classification is not having sufficient samples from mid-cap companies and no announcements small-cap final dividend. Highest positive maximum return in large-cap final dividend announcement and lowest minimum negative return observes in mid-cap final dividend announcement on the event day. Mean and median of full sample and large-cap abnormal returns are in negative and median is lower than respective means. Deviation of full sample and large-cap abnormal returns are very less.

Table 15. Event Day results for final dividend announcements rate 1000 and above percent by market capitalization wise

\begin{tabular}{lllllll}
\hline \multirow{2}{*}{ S. No. } & \multirow{2}{*}{ Sample Details } & \multicolumn{2}{l}{ Event day results } & & \\
\cline { 3 - 7 } & & AAR (\%) & CAAR (\%) & AAR t Stat & p Value & AAR Significance \\
\hline 4.6 .1 & Full sample & -0.364 & 0.114 & -0.878 & 0.388 & Not Significant \\
4.6 .2 & Large-cap & -0.428 & -0.754 & -1.021 & 0.319 & Not Significant \\
4.6 .3 & Mid-cap & \multicolumn{2}{l}{ Sufficient events are not available } & & \\
4.6 .4 & Small-cap & \multicolumn{2}{l}{ No events } & & & \\
\hline
\end{tabular}

Source: Author's calculations by using stock prices from bseindia.com.

Note: * significance at 5\% level.

From the above table 15, it can understand that full sample and large-cap final dividend announcements 1000 percent and above rate average abnormal returns are negative. Mid-cap final dividend announcement samples are not sufficient to test the returns and no events from small-cap final dividend announcements in this classification. Cumulative average abnormal returns in full sample slightly positive and large-cap slightly in negative. Calculated $\mathrm{p}$ values are higher than 0.05 value in full sample and large-cap final dividend announcements, so it means at a 5 percent significance level null hypothesis is not rejected. It can be interpreted that full sample and large-cap final dividend 1000 percent and above rate announcements do not impact on the stock prices at 5 percent level significance.

\subsection{Consolidation \\ a. Full sample Firms}

Table 16. Event Day results for full sample final dividend announcements in different dividend rate classifications

\begin{tabular}{|c|c|c|c|c|c|c|c|}
\hline \multirow{2}{*}{ S. No } & \multirow{2}{*}{ Classification } & \multirow{2}{*}{$\mathrm{N}$} & \multicolumn{5}{|c|}{ Event day results } \\
\hline & & & AAR $(\%)$ & CAAR $(\%)$ & AAR t Stat & $\mathrm{p}$ Value & AAR Significance \\
\hline 4.1 .1 & Dividend announcement $10 \%$ to $49 \%$ & 402 & 0.258 & 4.016 & 1.115 & 0.266 & Not Significant \\
\hline 4.3 .1 & Dividend announcement $100 \%$ to $199 \%$ & 432 & $0.330 *$ & 2.458 & 2.053 & 0.041 & Significant \\
\hline 4.4 .1 & Dividend announcement $200 \%$ to $499 \%$ & 348 & 0.112 & 0.037 & 0.667 & 0.505 & Not Significant \\
\hline 4.6 .1 & Dividend announcement $1000 \%$ and above & 25 & -0.364 & 0.114 & -0.879 & 0.388 & Not Significant \\
\hline
\end{tabular}

Source: Author's calculations by using stock prices from bseindia.com.

Note: * significance at $5 \%$ level. 
From the above tables16, it can interpret the different rates of dividend announcements by market capitalization wise impact on the stock price. The highest samples are in 50 percent to 99 final dividend rate, lowest tested samples in 1000 percent and above samples. In the full sample final dividend announcements, average abnormal returns (AAR) are positive in most of the rate classifications, but values are close to zero percent on the event day. It is observed the highest value in 100 percent to 199 percent rate classification and lowest value in 1000 percent and above classification. Cumulative average abnormal returns are also positive in most of the classifications except 500 percent to 999 percent classification. Higher positive CAAR observes in 10 percent to 49 percent and lower value in 500 percent to 999 percent classifications. Calculated p values are less than 0.05 in 100 percent to 199 percent only, and it means that the null hypothesis rejects for this classification and remaining in other classifications values are higher than 0.05 . So, it can be interpreted that full sample final dividend 100 percent to 199 percent announcement impact on stock prices and remaining in other classifications no impact on stock prices at a 5 percent significance level.

\section{b. Large-cap Firms}

Table 17. Event Day results for large-cap final dividend announcements in different dividend rate classifications

\begin{tabular}{llllllll}
\hline \multirow{2}{*}{ S. No } & \multirow{2}{*}{ Classification } & \multirow{2}{*}{ N } & \multicolumn{2}{c}{ Event day results } & & \\
& & & AAR (\%) & CAAR (\%) & AAR t Stat & p Value & AAR Significance \\
\hline 4.1 .2 & Dividend announcement 10\% to 49\% & 33 & -0.200 & 2.165 & -0.259 & 0.798 & Not Significant \\
4.2 .2 & Dividend announcement $50 \%$ to $99 \%$ & 89 & 0.267 & 0.820 & 1.010 & 0.315 & Not Significant \\
4.3 .2 & Dividend announcement $100 \%$ to $199 \%$ & 152 & 0.056 & 0.539 & 0.245 & 0.807 & Not Significant \\
4.4 .2 & Dividend announcement $200 \%$ to $499 \%$ & 153 & -0.130 & -0.527 & -0.525 & 0.600 & Not Significant \\
4.5 .2 & Dividend announcement $500 \%$ to $999 \%$ & 44 & 0.120 & -0.712 & 0.177 & 0.860 & Not Significant \\
4.6 .2 & Dividend announcement $1000 \%$ and above & 21 & -0.428 & -0.755 & -1.021 & 0.320 & Not Significant \\
\hline
\end{tabular}

Source: Author's calculations by using stock prices from bseindia.com.

Note.* significance@5\% level.

From the above table 17, in large-cap final dividend announcements, highest samples are in 200 percent to 499 final dividend rate, lowest tested samples in 1000 percent and above rate samples. Average abnormal returns are negative in 10 percent to 49 percent, 200 percent to 499 percent and 1000 percent and above final dividend rate, and remaining in other observations are positive on event day. It is observed the highest value in 50 percent to 99 final dividend rate and lowest in 1000 percent and above. Cumulative average abnormal return is negative in 200 percent and above, and remaining in other observations, returns are positive, but values are less on the event day. Calculated $\mathrm{p}$ values are higher than 0.05 in all large final dividend rate classifications; it means the null hypothesis not rejects for these observations. So, it can be interpreted that large-cap final dividend all rate announcements do not impact stock prices at a 5 percent significance level.

\section{c. Medium Cap Firms}

Table 18. Event Day results for mid-cap final dividend announcements in different dividend rate classifications

\begin{tabular}{llllllll}
\hline \multirow{2}{*}{ S. No } & \multirow{2}{*}{ Classification } & \multirow{2}{*}{ N } & \multicolumn{2}{l}{ Event day results } & & \\
& & & AAR (\%) & CAAR (\%) & AAR t Stat & p Value & AAR Significance \\
\hline 4.1 .3 & Dividend announcement $10 \%$ to $49 \%$ & 68 & 0.553 & 3.104 & 0.954 & 0.343 & Not Significant \\
4.2 .3 & Dividend announcement $50 \%$ to $99 \%$ & 112 & 0.014 & 1.604 & 0.047 & 0.963 & Not Significant \\
4.3 .3 & Dividend announcement $100 \%$ to $199 \%$ & 132 & 0.067 & 2.646 & 0.234 & 0.815 & Not Significant \\
4.4 .3 & Dividend announcement $200 \%$ to $499 \%$ & 84 & 0.328 & 0.088 & 1.019 & 0.311 & Not Significant \\
4.5 .3 & Dividend announcement 500\% to 999\% & 25 & 0.13 & -2.267 & 0.242 & 0.811 & Not Significant \\
4.6 .3 & Dividend announcement $1000 \%$ and above & 4 & Not sufficient events & & & & \\
\hline
\end{tabular}

Source: Author's calculations by using stock prices from bseindia.com.

Note.* significance @ 5\% level.

It can be said from the table 18 that, in mid-cap final dividend announcement, the highest samples are in 100 percent to 199 final dividend rate, lowest tested samples in 500 percent to 999 percent and above 1000 percent samples are not sufficient to run a test. Average abnormal returns are positive in all observations on the event day. It is observed the highest value in 10 percent to 49 final dividend rate and lowest in 50 percent to 99 percent. Cumulative average abnormal return is negative in the highest final dividend rates 500 percent to 999 percent and remaining in all other observations returns on the event day. Calculated $p$ values are higher than 0.05 in all 
final dividend rate classifications, and it means the null hypothesis not rejects for these observations. So, it can be interpreted that mid-cap final dividend all rate announcements do not impact stock prices at a 5 percent significance level.

\section{d. Small-cap Firms}

Table 19. Event Day results for small-cap final dividend announcements in different dividend rate classifications

\begin{tabular}{|c|c|c|c|c|c|c|c|}
\hline \multirow{2}{*}{ S. No } & \multirow{2}{*}{ Classification } & \multirow{2}{*}{$\mathrm{N}$} & \multicolumn{5}{|c|}{ Event day results } \\
\hline & & & AAR $(\%)$ & CAAR (\%) & AAR t Stat & $\mathrm{p}$ Value & AAR Significance \\
\hline 4.1 .4 & Dividend announcement $10 \%$ to $49 \%$ & 301 & 0.241 & 4.425 & 0.903 & 0.367 & Not Significant \\
\hline 4.3 .4 & Dividend announcement $100 \%$ to $199 \%$ & 148 & $0.847^{*}$ & 4.262 & 2.687 & 0.008 & Significant \\
\hline 4.4 .4 & Dividend announcement $200 \%$ to $499 \%$ & 111 & 0.280 & 0.775 & 0.888 & 0.376 & Not Significant \\
\hline 4.6.4 & Dividend announcement $1000 \%$ and above & 0 & \multicolumn{5}{|l|}{ No events } \\
\hline
\end{tabular}

Source. Author's calculations by using stock prices from bseindia.com.

Note. * significance at $5 \%$ level.

It can be interpreted from table 19 that, in small-cap final dividend announcements highest samples are in 10 percent to 49 final dividend rate, lowest tested samples in 200 percent to 499 percent and above 500 percent samples are not sufficient to run a test. Average abnormal returns are positive all observations on the event day. It is observed the highest value in 100 percent to 199 final dividend rate and lowest in 50 percent to 99 percent. Cumulative average abnormal returns are positive in all observations and values are very high on the event day. Calculated $\mathrm{p}$ values are less than 0.05 in 100 percent to 199 percent only, and it means the null hypothesis rejects for these classifications and remaining in other classifications values are higher than 0.05 . So, it can be interpreted that small-cap final dividend 100 percent to 199 percent announcement impact on stock prices and remaining in other classifications no impact on stock prices at a 5 percent significance level.

\section{Conclusion}

The present research study examined the impact of different dividend rate announcements on stocks prices in the Indian stock market. The results observe in 21 times based on market capitalization wise and dividend rate wise for final dividend announcement. The results of the study are not the same for different dividend rate classifications and different market capitalizations. The study found positive abnormal returns on event day in most of the classifications and it is similar to Litzenberger and Ramaswamy (1982), Asquith and Mullins Jr (1983), Grinblatt, Masulis and Titman (1984), Chen, Nieh, Da Chen, and Tang (2009) and many previous research results studied in major developed stock markets and emerging stock markets. Full sample and small-cap final dividend rate 100 percent to 199 percent average abnormal returns are positively significant and other final dividend rate classification abnormal returns are positive in most of the observations, but returns are not significant. Large-cap average abnormal returns are more sensitive to different dividend rates and small-cap reacts positively in all classifications. So, different market capitalization final dividend actions impact on stocks in India varies in different dividend rate classifications. Full sample and small-cap final dividend action abnormal returns are positively significant during final dividend rate 100 percent to 199 percent, so it concludes that returns in this observation might be influenced the full sample and small-cap final dividend action abnormal returns.

\section{References}

Amihud, Y., \& Li, K. (2006). The Declining Information Content of Dividend Announcements and the effects of Institutional Holdings. Journal of Financial and Quantitative Analysis, 41(3), 637-660. https://doi.org/10.1017/s0022109000002568

Asquith, P., \& Mullins, D. (1983). The Impact of Initiating Dividend Payments on Shareholders' Wealth. The Journal of Business, 56(1), 77-96. Retrieved from http://www.jstor.org/stable/2352747

Balu, B. M., Fuller, K. P., \& Van Ness, R. A. (2011). Short Selling around Dividend Announcements and Ex-dividend Days. Journal of Corporate Finance, 17(3), 628-639. https://doi.org/10.1016/j.jcorpfin.2010.11.001 
Below, S., \& Johnson, K. (1996). An analysis of shareholder reannouncement to dividend announcements in bull and bear markets. Journal of Financial and Strategic Decisions, 9(3), 15-26. Retrieved from https://studyfinance.com/jfsd/pdffiles/v9n3/below.pdf

Berdnikova, G., \&Rogova, E. (2013). The analysis of market re-announcement on dividend announcements of Russian companies. GSOM emerging Markets Conference: Business and Government Perspectives. Retrieved from https://ssrn.com/abstract=2511873

Bessembinder, H., \& Zhang, F. (2015). Predictable corporate distributions and stock returns. Review of Financial Studies, 28(4), 1199-1241. https://doi.org/10.1093/rfs/hhu145

Bessler, W., \& Nohel, T. (2000). Asymmetric Information, Dividend Reductions, and Contagion Effects in Bank Stock Returns. Journal of Banking and Finance, 24(11), 1831-1848. https://doi.org/10.1016/S0378-4266(99)00097-7

Brown, S. J., \& Warner, J. B. (1980). Measuring Security Price Performance. Journal of Financial Economics, $8(3), 205-258$.

Chavali, K., \& Nusratunnisa. (2013). Impact of Dividends on Share Price Performance of Companies in Indian Context. SDMIMD Journal of Management, 4(1), 4-9.

Chen, D. H., Liu, H. H., \& Huang, C. T. (2009). The Announcement Effect of Cash Dividend Changes on Share Prices: An Empirical Analysis of China. Chinese Economy, 42(1), 62-85. https://doi.org/10.2753/CES1097-1475420103

Corrado, C. J. (2011). Event studies: A methodology review. Accounting and Finance, 51(1), $207-234$. https://doi.org/10.1111/j.1467-629X.2010.00375.x

Dasilas, A., \& Leventis, S. (2011). Stock Market Re-announcement to Dividend Announcements: Evidence from Greek Stock Market. International Review of Economics and Finance, 20(2), 302-311. https://doi.org/10.1016/j.iref.2010.06.003

Del Brio, E. (2004). Insider Trading Around Dividend Announcements: The Spanish Evidence. http://dx.doi.org/10.2139/ssrn.492602

DissaBandara, P. H., \&Samarakoon, L. P. (2002). Dividend Announcements, Firm Size and Dividend in the Sri Lankan Stock Market.pdf. Sri Lanka Journal of Management, 7(2), 228-245.

Elfakhani, S. (1998). The Expected Favourableness of Dividend Signals, the Direction of Dividend Change and the Signalling Role of Dividend Announcements. Applied Financial Economics, 8(3), 221-230. https://doi.org/10.1080/096031098332989

Fama, E. F., \& French, K. R. (2000). Disappearing Dividends: Changing Firm Characteristics or Lower Propensity to Pay? AFA 2001 New Orleans; CRSP Working Paper No. 509. https://dx.doi.org/10.2139/ssrn.203092

Fama, E., Fisher, L., Jensen, M., \& Roll, R. (1969). The Adjustment of Stock Prices to New Information. International Economic Review, 10(1), 1-21. https://dx.doi.org/10.2307/2525569

Foster, T., \& D. Vickrey, (1978). The information content of stock dividend announcements. The Accounting Review, 53(2), 360-370.

Gunalp, B., Kadioglu, E., \& Killc, S. (2011). The Announcement Effect of Cash Dividend on Share Prices and the Tax Clientele Effect: Evidence from Turkish Capital Markets. Euro Conference 2011: Crises and Recovery in Emerging Markets. https://doi.org/10.13140/RG.2.1.2980.4400

Gupta, S., Dogra, B., Vashisht, A. K., \& Ghai, S. (2012). Stock Price Reannouncements to Dividend Announcements. International Journal of Management, 2(2), 23-31

Hussainey, K., Chijoke, O., \& Chijokemgbame, M. (2011). Dividend policy and share price volatility: UK evidence Dividend Policy and Share Price Volatility: UK Evidence. Journal of Risk Finance, 12(1), 57-68. https://doi.org/10.1108/15265941111100076

John, K., \& Larry, H. P. L. (1991). Insider Trading around Dividend Announcements: Theory and Evidence. The Journal of Finance,46(4), 1361-1389. https://dx.doi.org/10.2307/2328862

Kalay, A. (1982). The Ex-Dividend Day Behaviour of Stock Prices: A Re-Examination of the Clientele Effect. The Journal of Finance, 37(4), 1059-1070. https://dx.doi.org/10.2307/2327767 
Kempf, E., Manconi, A., \& Spalt, O. (2017). Distracted Shareholders and Corporate Announcements. Review of Financial Studies, 30(5), 1660-1695. https://doi.org/10.1093/rfs/hhw082

Kothari, S. P., \& Warner, J. B. (2007). Econometrics of Event Studies. Handbook of Empirical Corporate Finance SET, 2, 3-36. https://doi.org/10.1016/B978-0-444-53265-7.50015-9.

Litzenberger, R., \& Ramaswamy, K. (1982). The Effects of Dividends on Common Stock Prices Tax Effects or Information Effects? The Journal of Finance, 37(2), 429-443. https://dx.doi.org/10.2307/2327346

Marisetty, N. (2018). A Study on the Impact of Dividend Announcements on Stock Prices in Indian Capital Market. https://dx.doi.org/10.2139/ssrn.3145038

Marisetty, N., \& Babu, S. (2017). Corporate (Dividend) Announcements and Impact on Stock Abnormal Returns: A Study on Indian Context. International Journal of Management and Social Sciences Research, 6(11), 30-35.

Marisetty, N., \& Babu, S. (2018). Impact of Corporate Announcement (Different Stock Split Ratios) on StockPrice in India. International Journal of Research in Economics and Social Sciences, 8(1), 205-213.

Marisetty, N., \& Madasu, P. (2021). Corporate Announcements and Market Efficiency: A Case on Indian Capital Market. International Journal of Business and Management, 16(8), 71. https://doi.org/10.5539/ijbm.v16n8p71

Marisetty, N., \& Madasu, P. (2021). Signaling Hypothesis and Size Anomaly in Indian Stock Market. International Business Research, 14(9), 94. https://doi.org/10.5539/ibr.v14n9p94

Michaely, R., Rubin, A., \& Vedrashko, A. (2016). Are Friday announcements special? Overcoming selection bias. Journal of Financial Economics, 122(1), 65-85. https://doi.org/10.1016/j.jfineco.2016.05.006

Mishra, D., Racine, M. D., \& Schmidt, L. (2011). Credibility of corporate announcements and market reannouncement: Evidence from Canadian share repurchase programs. Canadian Journal of Administrative Sciences, 28(1), 83-100. https://doi.org/10.1002/cjas.127

Ngoc, D B., \& Cuong, N C. (2016). Dividend Announcement and Ex-dividend Announcement Effects on Stocks Returns. International Journal of Economics and Finance, 8(7), 207-215. DOI: 10.5539/ijef. v8n7p207

Schwert, G. W. W. (2005). Anomalies and Market Efficiency. SSRN Electronic Journal, https://doi.org/10.2139/ssrn.338080

Vieira, E., \& Raposo, C. (2007). Signalling with Dividends? The Signalling Effects of Dividend Change Announcements: New Evidence from Europe. Retrieved from http://dx.doi.org/10.2139/ssrn.955768

\section{Copyrights}

Copyright for this article is retained by the author(s), with first publication rights granted to the journal.

This is an open-access article distributed under the terms and conditions of the Creative Commons Attribution license (http://creativecommons.org/licenses/by/4.0/). 